\title{
Metabolism of Exogenous Arginine and Glucose by Starved Streptococcus lactis in Relation to Survival
}

\author{
By T. D. THOMAS* AND R. D. BATT \\ New Zealand Dairy Research Institute, Palmerston North, New Zealand, and \\ Chemistry and Biochemistry Department, Massey University, Palmerston North, \\ New Zealand
}

\section{(Accepted for publication 7 July 1969)}

\section{SUMMARY}

Arginine or glucose accelerated death of Streptococcus lactis starved in phosphate buffer. Both substrates were metabolized at linear but different rates and the rate of ATP production from glucose metabolism was about 7.5 times that for arginine metabolism. $\mathbf{M g}^{2+}$ reduced glucose-accelerated death and abolished arginine-accelerated death to prolong survival. When glucose was fed continuously to organisms starved in phosphate buffer containing $\mathrm{Mg}^{2+}$, survival was related to the rate of glucose addition and hence to the rate of metabolism. By feeding low concentrations of glucose, the viability of most of the population was extended from about I to 4 days. The maintenance energy requirement appeared to be in the region of 0.045 to $0.09 \mathrm{mg}$. glucose/mg. dry wt bacteria/hr. The glycolytic activity of starved organisms declined at varying rates depending on the starvation environment but could not be correlated directly with loss of viability. Exogenous arginine substantially reduced the lethal effect of adverse $\mathrm{pH}$ values.

\section{INTRODUCTION}

Streptococcus lactis ferments carbohydrate mainly by means of the EmbdenMeyerhof pathway, and in an earlier investigation (Thomas \& Batt, 1969a) the lactic acid produced was found to account for approximately $93 \%$ of the glucose fermented. Apart from carbohydrate, arginine is the only substrate reported from which $S$. lactis can obtain energy. Catabolism of arginine by $S$. lactis produced ornithine, carbamyl phosphate and ammonia and the enzymes catalysing these reactions were characterized by Korzenovsky \& Werkman (1953, I954). When $S$. lactis was starved in the presence of a fermentable carbohydrate, accelerated death occurred (Thomas \& Batt, I968). Addition of $\mathrm{Mg}^{2+}$ reduced this effect while incubation of starved organisms with arginine plus $\mathrm{Mg}^{2+}$ gave extended survival indicating that the nature of the energy source was critical for survival.

Postgate \& Hunter (1962) reported that glycerol-limited Aerobacter aerogenes died more rapidly when washed and starved in phosphate buffer containing glycerol than in phosphate buffer alone. This phenomenon was termed 'substrate-accelerated death' and has since been investigated intensively for $A$. aerogenes (see review by Postgate, 1967). Strange \& Dark (1965) reported that the death rate of $A$. aerogenes increased with the rate of substrate metabolism while exogenous $\mathrm{Mg}^{2+}$ decreased the rate of

* Present address: Sub-Department of Chemical Microbiology, Department of Biochemistry, University of Cambridge, Cambridge, Great Britain. 
degradation of intracellular RNA without significantly affecting substrate metabolism. The mechanism of substrate-accelerated death is not fully understood. However, Strange \& Dark (1965) attributed glycerol-accelerated death, at least in part, to the formation of an unidentified toxic product of glycerol metabolism. They suggested that added $\mathrm{Mg}^{2+}$ prevented the accumulation or formation of this product. During glucose-accelerated death of $A$. aerogenes the bacterial ATP pool increased significantly whereas in the presence of glucose plus $\mathrm{Mg}^{2+}$ there was little change (see Discussion, Strange \& Hunter, 1967). In this connexion, Postgate \& Hunter (1964) showed that glycerol-accelerated death of $A$. aerogenes was largely abolished by uncoupling agents. Any proposed mechanism should be consistent with the fact that while exogenous glucose accelerates death the death rate may decrease in parallel with increasing intracellular polyglucose levels (Strange, Dark \& Ness, 196I).

In contrast to the effect of carbon substrates on starving organisms discussed above however, there are several recent reports of decreased death rates resulting from the intermittent addition of small amounts of glucose to Escherichia coli starved in buffer containing $\mathrm{Mg}^{2+}$ (Clifton, I966; McGrew \& Mallette, I962, I965; Mallette, 1963). However, the evaluation of some of these results is difficult since the experimental procedure did not preclude regrowth (see Dawes \& Ribbons, 1964; Postgate, 1967).

The present investigation was undertaken in an attempt to define the role of exogenous, energy-yielding substrates in relation to bacterial survival.

\section{METHODS}

General procedures. The organism (Streptococcus lactis $\mathrm{ML}_{3}$ ), the conditions of growth and starvation and the methods used for determining bacterial mass and viability were described in preceding papers (Thomas \& Batt, 1968, 1969b). With experiments which involved the continuous feeding of glucose, washed organisms suspended in phosphate buffer were placed in a triple-necked quickfit flask (I400 ml. capacity) held in an incubator at $30^{\circ}$. The culture was agitated by a magnetic stirrer and phosphate buffer containing glucose was added at a constant flow rate using a D.C.L. Micropump (F. A. Hughes and Co., England) attached to a reservoir flask fitted with a constant head device.

Analytical methods. The products of arginine metabolism were estimated using the basic column of a Beckman model I $20 \mathrm{C}$ automatic amino acid analyser. The glycolytic activity of starved organisms was determined by the method of Thomas \& Batt (1969a).

\section{RESULTS}

The effect of energy sources on the survival of starved Streptococcus lactis is shown in Fig. I. Both arginine and glucose accelerated the death rate. $\mathbf{M g}^{2+}$ reduced glucoseaccelerated death while arginine $+\mathbf{M g}^{2+}$ gave extended survival times.

Arginine was metabolized at a linear rate of $2.35 \mu \mathrm{mole} / \mathrm{mg}$. dry wt bacteria/hr (Fig. 2). This rate theoretically corresponds to $2.35 \mu$ mole ATP/mg. dry wt bacteria $/ \mathrm{hr}$ (based on the stoichiometric reaction:

$$
\text { arginine } \left.+\mathrm{H}_{2} \mathrm{O}+\mathrm{P}_{1}+\mathrm{ADP} \rightarrow \text { ornithine }+2 \mathrm{NH}_{3}+\mathrm{CO}_{2}+\mathrm{ATP}\right) .
$$

The glycolytic activity of Streptococcus lactis $\mathrm{ML}_{3}$ was $0.29 \mu$ mole lactate/mg. dry wt bacteria/min. (Thomas \& Batt, I 969 ) and, since anaerobic fermentation of 
glucose produces I mole of ATP/mole lactate, this glycolytic activity represents the formation of $17.7 \mu \mathrm{mole}$ ATP $/ \mathrm{mg}$. dry wt bacteria/hr. Therefore the theoretical rate of ATP generation by $S$. lactis is about 7.5 times greater with Io mM-glucose than with Io mM-arginine. Arginine metabolism yielded the theoretical amount of ornithine and slightly less than the theoretical amount of ammonia (Fig. 2), confirming the findings of Korzenovsky \& Werkman (1954). In earlier survival experiments (Thomas \& Batt, 1968) washed suspensions with $20 \mu \mathrm{g}$. dry wt bacteria $/ \mathrm{ml}$. were incubated with Io mM-arginine. Assuming the above linear rate, these organisms would require more than $200 \mathrm{hr}$ for complete arginine metabolism, so that arginine was probably not limiting in these experiments.

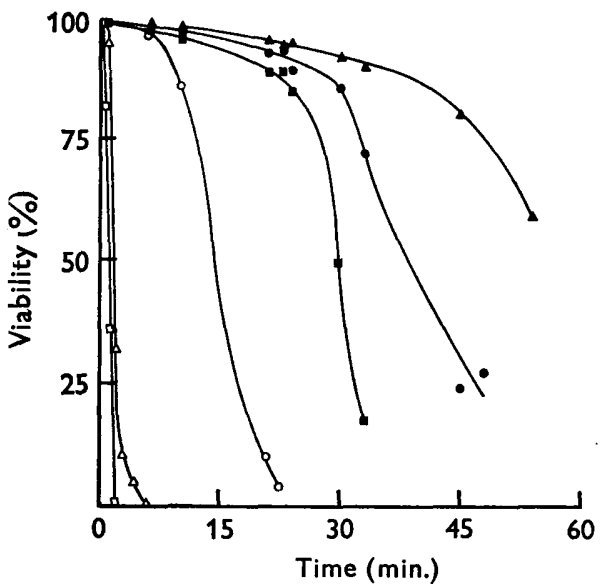

Fig. I

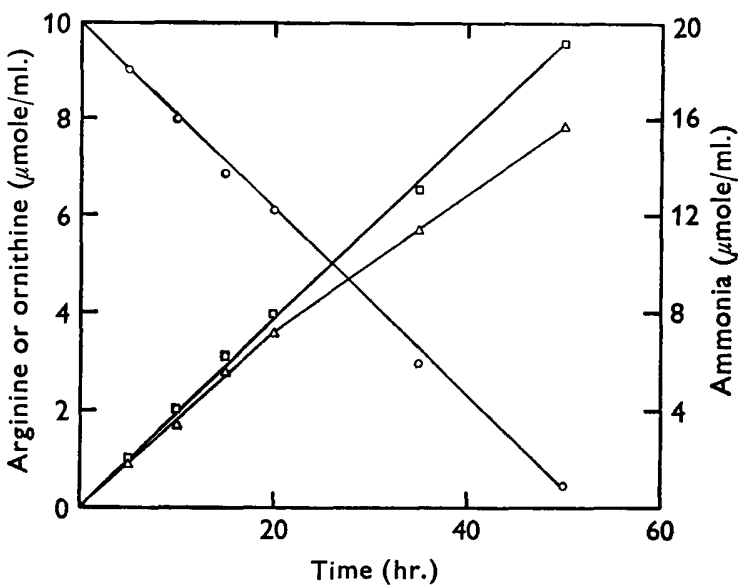

Fig. 2

Fig. I. Effect of glucose and arginine on survival of Streptococcus lactis. Washed organisms, harvested from the end of the growth phase in routine medium, were resuspended at $20 \mu \mathrm{g}$. dry $\mathrm{wt} / \mathrm{ml}$. in $0.075 \mathrm{M}$-phosphate buffer ( $\mathrm{pH} \mathrm{7.0,} \mathrm{10} \mu \mathrm{M}$-EDTA) containing: $O$, no addition; , I mM-MgSO ${ }_{4} ; \square$, 10 mM-glucose; $\mathbf{n}$, 10 mM-glucose + I mM-MgSO ${ }_{4} ; \triangle$, 10 mM-arginine; $\Delta$, $10 \mathrm{~mm}$-arginine $+\mathrm{I} \mathrm{mM}_{-} \mathrm{MgSO}_{4}$. Cultures were incubated at $30^{\circ}$ and viability was determined by slide-culture.

Fig. 2. Arginine metabolism by Streptococcus lactis. Bacteria were harvested from the routine medium at the end of the growth phase, washed twice and resuspended in $0.075 \mathrm{M}-$ phosphate buffer (pH 7.0; containing Io $\mu \mathrm{M}$-EDTA, I mM-MgSO ${ }_{4}$ and $10 \mathrm{~mm}$-L-arginine). The organisms were incubated at $30^{\circ}$ at $4.9 \mathrm{mg}$. dry wt $/ \mathrm{ml}$. At intervals, samples were withdrawn, immediately cooled to $-\mathrm{IO}^{\circ}$, centrifuged and the supernatants filtered. Supernatant samples were frozen $\left(-20^{\circ}\right)$ and later analysed for arginine $(O)$, ornithine $(\square)$ and ammonia $(\triangle)$, using the basic column of an amino acid analyser (see Methods).

Certain published findings with other bacteria have suggested that the extended survival of starved Streptococcus lactis with added arginine, as compared with glucose, may have been due to a lower rate of substrate metabolism (see Discussion). In order to test this possibility, experimental conditions were established so that glucose could be fed continuously to starved organisms. Buffered glucose solutions were added to cultures at constant flow rates with different glucose concentrations being used in each experiment. Some typical results of viability measurements on the starved organisms are shown in Fig. 3. Starved $S$. lactis is capable of fermenting glucose at a maximum rate of about $8 \cdot 8 \mu \mathrm{mole} / \mathrm{mg}$. dry wt bacteria/hr (Thomas \& Batt, I969a). 
When glucose was fed continuously to starved organisms in excess of this rate the death rate increased as expected (Fig. 3). By adding $\mathrm{I} \cdot 5 \mu$ mole glucose $/ \mathrm{mg}$. dry wt bacteria/hr, a level which would be expected to produce ATP at about the same rate as added arginine (see above), the survival curve resembled that of organisms starved in the presence of arginine $+\mathrm{Mg}^{2+}$ (Fig. I). Feeding lower levels of glucose further enhanced survival until an optimum level was reached at 0.25 to $0.5 \mu$ mole glucose $/ \mathrm{mg}$. dry wt bacteria/hr (Fig. 3). After $120 \mathrm{hr}$ starvation at a feed rate of $0.25 \mu$ mole glucose/mg. dry wt bacteria/hr (viability $40 \%$ ), organisms were harvested for examination by electron microscopy (Thomas \& Batt, 1969d).

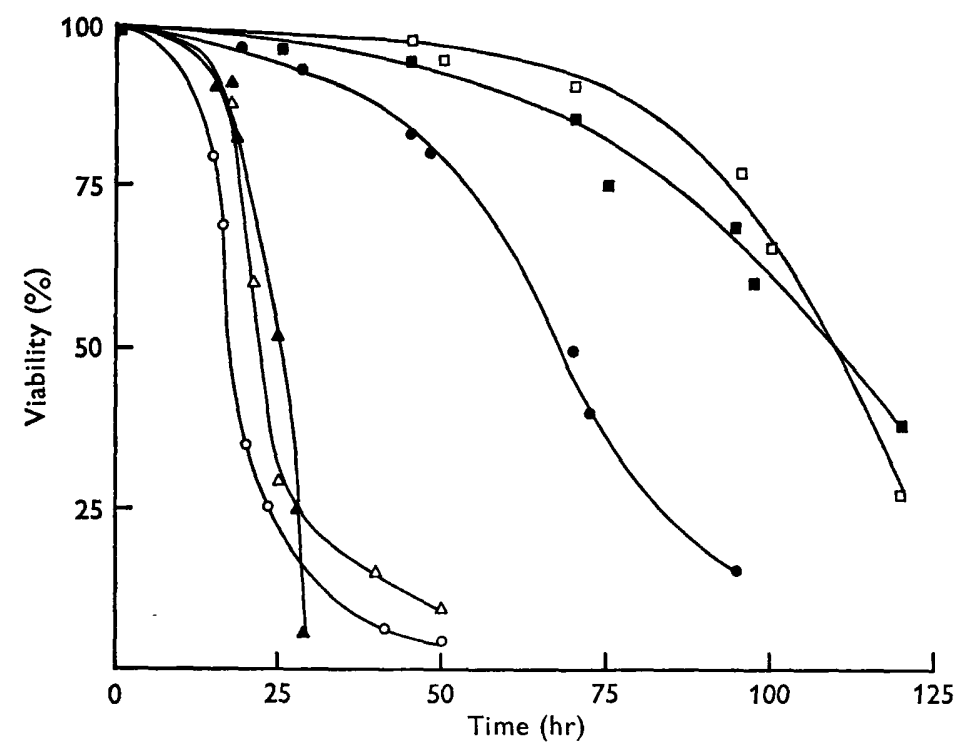

Fig. 3. Effect of feeding starved Streptococcus lactis continuously with different concentrations of glucose. For each experiment, washed organisms harvested from $35 \mathrm{ml}$. routine medium were resuspended at $30^{\circ}$ in $500 \mathrm{ml}$. $0.075 \mathrm{M}$-phosphate buffer ( $\mathrm{pH} 7.0$ ) containing I mM$\mathrm{MgSO}_{4}$ and $10 \mu \mathrm{M}$-EDTA. The initial bacterial mass was $45-50 \mu \mathrm{g}$. dry $\mathrm{wt} / \mathrm{ml}$. Phosphate buffer, containing different glucose concentrations in each experiment, was added continuously ( 13 additions $/ \mathrm{min}$.) to the stirred culture at a flow rate of $7 \cdot 0 \mathrm{ml} . / \mathrm{hr}$. Samples $(0.2 \mathrm{ml}$ ) were removed periodically for determination of viability, $\mathrm{pH}$ and turbidity. Glucose feed rates $\left(\mu\right.$ mole glucose/mg. dry wt bacteria/hr) were: $0, I_{5} \cdot 0 ; 0,1.5 ; \square, 0.5$; 口, $0.25 ; \Delta, 0.05 ; \Delta, 0.00$.

Starved cultures were progressively diluted but since survival was independent of bacterial density in the presence of added $\mathrm{Mg}^{2+}$ (Thomas \& Batt, I968), this should not have influenced the present results. The $\mathrm{pH}$ drop was always less than $0 \cdot 15$ units. At low feed rates the turbidity of starved cultures, after correction for dilution, showed a slow decline while at higher feed rates the decline was more rapid. At low glucose feed rates, viable organisms after 50 to $\mathrm{I} 00 \mathrm{hr}$ starvation had short division lag times similar to those at the onset of starvation. By contrast, rapid glucose metabolism gave rise to long division lags (Thomas \& Batt, 1968) and more rapid RNA breakdown (Thomas \& Batt, $1969 b$ ).

Organisms which were starved under conditions giving the maximum range of 
death rate were examined for comparative glycolytic activities. No general correlation between glycolytic activity and survival was found (Table I). Incubation of starved organisms with glucose caused a more rapid loss of glycolytic activity (Table I). With the bacterial concentration used, Io mM-glucose was metabolized in about $5 \mathrm{hr}$ and Io mM-arginine in about $20 \mathrm{hr}$. The survival curve for the high glucose feed rate flattened off unexpectedly (Fig. 3), possibly as a result of decreased glycolytic activity. Similarly the survival curves at low feed rates flattened off at low viabilities but in these experiments the lower glucose feed rates may have been capable of supporting only part of the total population.

\title{
Table I. Glycolytic activity of starved Streptococcus lactis
}

\begin{abstract}
Organisms were washed and resuspended at $30^{\circ}$ in $100 \mathrm{ml} .0 .075 \mathrm{M}$-phosphate buffer $(\mathrm{pH} 7.0$, Io $\mu \mathrm{M}$-EDTA) containing the additions given in the first column. The cell mass was $0.21 \mathrm{mg}$. dry $\mathrm{wt} / \mathrm{ml}$. At intervals, samples ( $10 \mathrm{ml}$.) were removed and centrifuged, the organisms were washed and resuspended in phosphate buffer $(2 \mathrm{ml}$.) and the glycolytic activity determined as described in Methods. Glycolytic activity is given in terms of $\mu$ moles lactate $/ \mathrm{mg}$. dry wt bacteria/min., \% viabilities are given in parentheses.
\end{abstract}

Time (hr)

$\begin{array}{llllllll}0.5 & 1.5 & 3 & 5 & 8 & \text { I0 } & 22 & 27 \\ \text { Glycolytic activity } & & & \end{array}$
None

Additions to above buffer

$+\mathrm{MgSO}_{4}(\mathrm{I} \mathrm{mM})$

$+\mathrm{MgSO}_{4}(\mathrm{I} \mathrm{mM})+\mathrm{L}$-arginine (10 $\left.\mathrm{mM}\right)$

$+\mathrm{MgSO}_{4}$ (I mM) + L-arginine (Io mM)

+ casamino acids $(0.5 \%)$

+ Glucose (10 mM)

$+\mathrm{MgSO}_{4}(\mathrm{I} \mathrm{mM})+$ glucose (Io mM)

\begin{tabular}{|c|c|c|c|c|c|c|c|}
\hline 14 & 247 & 230 & $\begin{array}{c}0.194 \\
(96)\end{array}$ & $\begin{array}{l}0.175 \\
(57)\end{array}$ & $\begin{array}{c}0.174 \\
(15)\end{array}$ & $\begin{array}{l}0.155 \\
\text { (I) }\end{array}$ & 0 \\
\hline & 0.264 & 4 & $\begin{array}{c}0.206 \\
\text { (99) }\end{array}$ & & $\begin{array}{c}0.164 \\
(98)\end{array}$ & $\begin{array}{c}0.158 \\
(72)\end{array}$ & \\
\hline & & 52 & 0.218 & 0.189 & & $\begin{array}{c}0.148 \\
(98)\end{array}$ & \\
\hline & & $24 I$ & 0 & 178 & $\begin{array}{c}0.170 \\
(98)\end{array}$ & $\begin{array}{c}0.157 \\
(95)\end{array}$ & \\
\hline & $\begin{array}{r}0.24 \\
(72)\end{array}$ & $\begin{array}{r}0.181 \\
\text { (19) }\end{array}$ & & $\begin{array}{l}0.137 \\
\text { (I) }\end{array}$ & 0.118 & 0.052 & 045 \\
\hline & & & $\begin{array}{l}\cdot \text { I I I I } \\
\text { (99) }\end{array}$ & $\begin{array}{c}0.121 \\
(84)\end{array}$ & $\begin{array}{c}0.091 \\
(61)\end{array}$ & $\begin{array}{c}0.016 \\
(23)\end{array}$ & (4) \\
\hline
\end{tabular}

Starved organisms were previously shown to be very sensitive to $\mathrm{pH}$ changes, the optimum pH for survival being near $7 \cdot 0$ (Thomas \& Batt, 1968). Since Dawes \& Ribbons (1962, 1964) have suggested that an energy source is required for intracellular $\mathrm{pH}$ control in starved bacteria it seemed appropriate to re-examine the $\mathrm{pH}$ effect on Streptococcus lactis in the presence of an added energy source. As addition of either carbohydrate or arginine alone produced accelerated death of starved S. lactis (Fig. I) it was decided to re-examine the $\mathrm{pH}$ effect with added $\mathrm{Mg}^{2+}$, which abolished arginineaccelerated death (Fig. $\mathrm{I}$ ), in addition to incubations with arginine $+\mathbf{M g}^{2+}$. Addition of $\mathrm{Mg}^{2+}$ decreased the death rate at all $\mathrm{pH}$ values (Fig. $4 \mathrm{~b}$ ), while arginine $+\mathrm{Mg}^{2+}$ produced a further marked decrease in the death rates (Fig. $4 c$ ). The initial pH values in Fig. $4(a),(b)$ did not change significantly over the starvation period. After $48 \mathrm{hr}$ starvation with Io mM-arginine (Fig. $4 c$ ), initial $\mathrm{pH}$ values had risen by only about $0.2 \mathrm{pH}$ units. This rise was presumably due to ammonia production. 


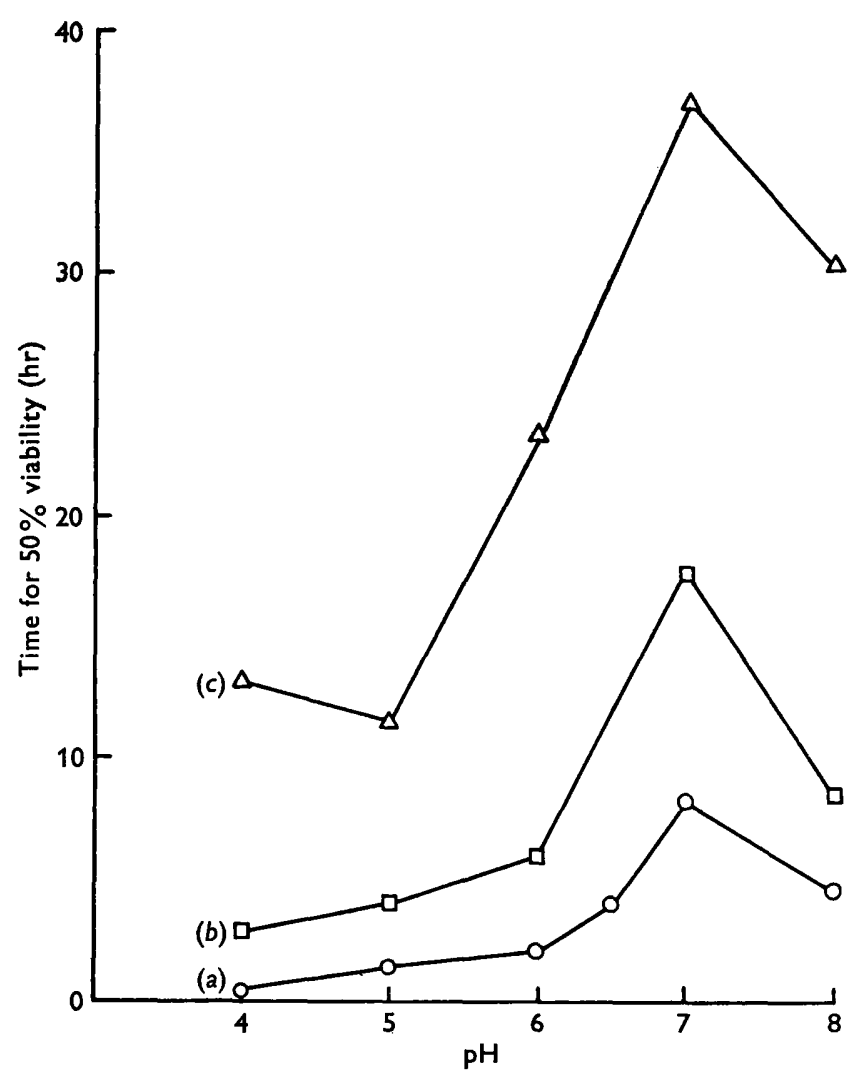

Fig. 4. Effect of $\mathrm{pH}$ on survival of Streptococcus lactis $\mathrm{ML}_{\mathbf{3}}$. Buffers were prepared from $0.1 \mathrm{M}-\mathrm{Na}_{2} \mathrm{HPO}_{4}$ and $0.05 \mathrm{M}$-citric acid containing $10 \mu \mathrm{M}-\mathrm{EDTA}$. Curve $(a)$. Bacteria were harvested from $20 \mathrm{ml}$. culture at the end of the growth phase, washed and resuspended in $5 \mathrm{ml}$. phosphate-citrate buffer $\left(\mathrm{pH}_{7} \cdot 0\right), 0.5 \mathrm{ml}$. of this suspension was added to $10 \mathrm{ml}$. buffer at $30^{\circ}$ to give $190 \mu \mathrm{g} . / \mathrm{ml}$. and final $\mathrm{pH}$ values indicated. Curve $(b)$. Suspensions prepared as for (a) at similar $\mathrm{pH}$ values; each suspension contained I $\mathrm{mM}-\mathrm{Mg}^{2+}$. Curve $(c)$. Suspensions prepared as for $(a)$ but at $80 \mu \mathrm{g}$. dry wt bacteria/ml. The buffer contained $10 \mathrm{~mm}$-arginine $+\mathrm{I} \mathrm{mM}^{-\mathrm{MgSO}_{4}}$ and $\mathrm{pH}$ values were adjusted to those above by addition of $\mathrm{HCl}$. Results were graphed and a summary is presented. Before viability determination samples were diluted in phosphate-citrate buffer containing $\mathbf{I} \mathbf{~ m M - \mathbf { M g } ^ { 2 + }}(\mathrm{pH} 7 \cdot 0)$.

\section{DISCUSSION}

The addition of either glucose or arginine to Streptococcus lactis starved in phosphate buffer resulted in accelerated death while the presence of $\mathrm{Mg}^{2+}$ either reduced or eliminated this effect. The only metabolic product likely to be common to both glucose and arginine metabolism is ATP. Both arginine and glucose were metabolized at constant rates by starved organisms and the rate of ATP generation was calculated to be about 7.5 times greater with Io mM-glucose than with Io mM-arginine, in agreement with the results of Forrest (1965) for starved Streptococcus faecalis. Assuming $93 \%$ conversion, a glycolytic activity of $0.29 \mu \mathrm{mole}$ lactate $/ \mathrm{mg}$. dry wt bacteria/min. corresponds to fermentation of about $\mathrm{I} \cdot 7 \mathrm{mg}$. glucose $/ \mathrm{mg}$. dry wt bacteria/hr. Even allowing for energy yield differences from glucose metabolism, this rate was much greater than 
the maintenance energy requirement of approximately $0.07-0.09 \mathrm{mg}$. glucose $/ \mathrm{mg}$. dry wt bacteria/hr for aerobic metabolism of Escherichia coli, Aerobacter aerogenes and Aerobacter cloacae (see Pirt, 1965). Assuming a similar maintenance energy'requirement for $S$. lactis, then clearly there is no economy of metabolic energy for maintenance of starved $S$. lactis and the linear rate of glucose fermentation (Thomas \& Batt, I969a) indicates that the metabolism of starved organisms continues at rapid rates. From data obtained for the growth of S. lactis (Thomas, 1968) it can be calculated that growing organisms should produce approximately $\mathrm{I} \cdot 2 \mu$ moles lactate $/ \mathrm{mg}$. dry wt bacteria/min. while glycolytic activity measurements (Thomas \& Batt, 1969a), showed that non-growing organisms produced $0.29 \mu$ mole lactate $/ \mathrm{mg}$. dry wt bacteria $/ \mathrm{min}$. A simple explanation for the observed linear rates of glycolysis and arginine fermentation in starved $S$. lactis would be that these processes were not subject to feedback control and hence ATP could be generated in amounts which were far in excess of requirements. A similar conclusion was drawn by Forrest \& Walker (I965a) using S. faecalis.

It seemed possible that the extended survival of starved Streptococcus lactis organisms with added arginine, compared with glucose, was due to the lower rate of ATP production since McGrew \& Mallette (1962) reported an increase in the survival times of starved Escherichia coli on the intermittent addition of very small amounts of glucose. In contrast, most other workers have used relatively high carbohydrate/cell mass ratios and have not observed extended survival. Glycerol- and succinateaccelerated death decreased on reducing the substrate concentration and was undetectable at low concentrations (Postgate \& Hunter, 1964). It could be informative to re-examine the effect of low glycerol concentrations on survival in the presence of added $\mathrm{Mg}^{2+}$. Strange \& Dark (1965) have observed that increased rates of glycerol oxidation produced increased death rates adding to a considerable amount of evidence which suggested that the rate of substrate metabolism, and the rate of ATP production, may be critical for survival. In the present investigation experiments involving the continuous addition of glucose to starved $S$. lactis indicated that survival was profoundly affected by the rate of glucose metabolism. An optimum feed rate of 0.25$0.5 \mu$ mole glucose $/ \mathrm{mg}$. dry wt bacteria/hr extended survival from about $\mathrm{I}$ to 4 days. This corresponds to a maintenance energy requirement for starved $S$. lactis of approximately $0.045^{-0.09} \mathrm{mg}$. glucose $/ \mathrm{mg}$. dry wt bacteria/hr which is of the same order as that reported for aerobic bacteria (see Pirt, 1965). Although glucose fermentation by $S$. lactis yields less energy than in aerobic organisms, Marr, Nilson \& Clark (I963) calculated that for $E$. coli approximately half the maintenance energy requirement may be used for resynthesis so that the actual maintenance requirement for $S$. lactis may be lower than that for $E$. coli since resynthesis of protein and RNA by starved $S$. lactis occurs to a much more limited extent (Thomas \& Batt, 1969c).

In the absence of $\mathrm{Mg}^{2+}$, the death rate of $S$. lactis when harvested from the lactoselimited growth medium and starved in phosphate buffer was accelerated to similar degrees by the addition of either glucose, galactose, fructose or lactose (Thomas \& Batt, I968), all of which are considered to be metabolized via the glycolytic pathway. By contrast, the death rate of glycerol-limited Aerobacter aerogenes was not accelerated by added glucose or ribose (Postgate \& Hunter, 1964). Although these substrates were shown to be metabolized, there was no indication that the rate of their metabolism was similar to that in organisms grown with glucose or ribose limitations where these 
substrates accelerated the death rate of starved organisms. Since the activity of constitutive enzymes may vary according to growth conditions (Pardee, I96I), it seems possible that substrates not included in the growth medium may be metabolized at slower rates by starved organisms. However, the strain of $A$. aerogenes used by Strange \& Dark (1965) showed carbon-accelerated death with carbon sources besides the one which had been used as the growth-limiting substrate.

Several reports have indicated that rapid metabolism of energy-yielding substrates by starved bacteria is accompanied by an increased rate of polymer hydrolysis (e.g. Strange \& Dark, 1965; Thomas \& Batt, 1969b) while other investigations have demonstrated that the breakdown of protein and nucleic acid in starved bacteria is suppressed by agents inhibiting energy-yielding reactions (see Halvorson, 1962). Slow substrate metabolism may supply the maintenance energy requirement without deleterious effects.

The metabolism of exogenous substrates does not always appear to be coupled to the energy requirements of starved organisms and it seems possible that the rapid depletion of reserve polymers in some bacteria may present a similar situation with respect to endogenous substrates. Burleigh \& Dawes (1967) have suggested that the rapid metabolism of polyglucose may cause substrate-accelerated death. Reserve polymers may exert a sparing action on essential cell constituents but they seem to enhance survival only if they are broken down at comparatively slow rates (e.g. see Strange et al. 196I ; Sierra \& Gibbons, 1962; Sobek, Charba \& Foust, 1966; Zevenhuizen, 1966). However, Strange \& Hunter (1967) also pointed out that the enhanced survival of nitrogen-limited Aerobacter aerogenes may be due to the relatively high $\mathrm{Mg}^{2+}$ content rather than the glycogen reserves.

In a number of starvation environments, the glycolytic activity of Streptococcus lactis fell steadily from the onset of starvation and was not correlated with viability. Other workers have, however, found a correlation between the activity of the catabolic enzymes and survival in support of an early hypothesis associating bacterial death with enzyme inactivation (Rahn \& Schroeder, 194I). For example, Postgate \& Hunter (1962) found that the glycerol dehydrogenase and glycerol oxidase activities of starved Aerobacter aerogenes declined in parallel with viability, while the endogenous respiration rate of the glycerol-limited organisms was not directly related and, in fact, declined more rapidly. Similarly, Burleigh \& Dawes (1967) reported a correlation between the survival of aerobically starved Sarcina lutea and their ability to oxidize exogenous glutamate and glucose. In the present study the glycolytic activity of $S$. lactis was not maintained with exogenous carbohydrates or amino acids including arginine, in contrast to the findings of Walker \& Forrest (1964) and Forrest \& Walker (1965b) with Streptococcus faecalis. Indeed, added glucose produced a more rapid decline in glycolytic activity.

Although it has been proposed that energy is required for intracellular $\mathrm{pH}$ control in starved bacteria (Dawes \& Ribbons, 1962, 1964), this has not been experimentally demonstrated. Streptococcus lactis had a sharp $\mathrm{pH}$ optimum for survival which is perhaps consistent with the absence of an endogenous energy source. In this connexion, the addition of arginine was shown to produce a marked decrease in death rates at all $\mathrm{pH}$ values. At acid $\mathrm{pH}$ values this effect could have been due to a neutralizing action of the $\mathrm{NH}_{3}$ produced from arginine metabolism. However, arginine also prolonged survival at alkaline $\mathrm{pH}$ and it seemed likely that the energy produced from 
arginine metabolism was directly responsible for reducing the lethal effect of adverse $\mathrm{pH}$ values.

The growth of lactic acid bacteria in milk normally ceases when the lactic acid formed produces inhibitory acid conditions. Although growth ceases, the organisms remain viable and continue to ferment the large excess of lactose present but at a much slower rate. It is possible that the energy produced by the continuing fermentation could be an important factor for the survival of these organisms in sour milk.

We thank Dr R. C. Lawrence for many helpful discussions.

\section{REFERENCES}

Burleigh, I. G. \& Dawes, E. A. (1967). Studies on the endogenous metabolism and senescence of starved Sarcina lutea. Biochem. J. 102, 236.

Curfton, C. E. (1966). Ageing in Escherichia coli. J. Bact. 92, 905.

Dawes, E. A. \& RibBons, D. W. (1962). The endogenous metabolism of microorganisms. A. Rev. Microbiol. 16, 24I.

Dawes, E. A. \& RiBbons, D. W. (1964). Some aspects of the endogenous metabolism of bacteria. Bact. Rev. 28, 126.

FORREST, W. W. (1965). Adenosine triphosphate pool during the growth cycle in Streptococcus faecalis. J. Bact. 90, I0I3.

FORREST, W. W. \& WALKER, D. J. (1965a). Synthesis of reserve materials for endogenous metabolism in Streptoccocus faecalis. J. Bact. 89, 1448.

ForRest, W. W. \& WALKER, D. J. (1965b). Control of glycolysis in washed suspensions of Streptococcus faecalis. Nature, Lond. 207, 46.

Halvorson, H. O. (1962). The function and control of intracellular protein turnover in microorganisms. In Amino Acid Pools. Ed. by J. T. Holden. p. 646. Amsterdam: Elsevier.

Korzenovsky, M. \& Werkman, C. H. (I953). Conversion of citrulline to ornithine by cell-free extracts of Streptococcus lactis. Archs Biochem. Biophys. 46, 174.

KorZENOVSKY, M. \& WERKMAN, C. H. (1954). Stoichiometry of the citrulline phosphorylase reaction of Streptococcus lactis. Biochem. J. 57, 343.

Malletre, M. F. (1963). Validity of the concept of energy of maintenance. Ann. N.Y. Acad. Sci. ro2, 521 .

MARR, A. G., NIISON, E. H. \& ClARK, D. J. (1963). The maintenance requirement of Escherichia coli. Ann. N.Y. Acad. Sci. ro2, 536.

McGrew, S. B. \& MALLETTE, M. F. (1962). Energy of maintenance of Escherichia coli. J. Bact. 83, 844 .

McGrew, S. B. \& MALLETTE, M. F. (1965). Maintenance of Escherichia coli and the assimilation of glucose. Nature, Lond. 208, I096.

Pardee, A. B. (I96I). Response of enzyme synthesis and activity to environment. In Microbial Reaction to Environment. Symp. Soc. gen. Microbiol. II, 19.

PiRT, S. J. (1965). The maintenance energy of bacteria in growing cultures. Proc. R. Soc. B r63, 224.

Postgate, J. R. (1967). Viability measurements and the survival of microbes under minimum stress. Adv. microb. Physiol. I, I.

Postgate, J. R. \& HunteR, J. R. (1962). The survival of starved bacteria. J. gen. Microbiol. 29, 233.

Postgate, J. R. \& HUNTER, J. R. (1964). Accelerated death of Aerobacter aerogenes starved in the presence of growth-limiting substrates. J. gen. Microbiol. 34, 459.

RAHN, O. \& SCHROEDER, W. R. (I94I). Inactivation of enzymes as the cause of death in bacteria. Biodynamica 3, 199.

SIERRA, G. \& GIBBONS, N. E. (1962). Role and oxidation pathway of poly- $\beta$-hydroxybutyric acid in Micrococcus halodenitrificans. Can. J. Microbiol. 8, 255.

SobeK, J. M., Charba, J. F. \& Foust, W. N. (I966). Endogenous metabolism of Azotobacter agilis. J. Bact. 92, 687.

Strange, R. E. \& Dark, F. A. (1965). 'Substrate-accelerated death' of Aerobacter aerogenes. J. gen. Microbiol. 39, 215. 
STRANGE, R. E. \& HUNTER, J. R. (1967). Effect of magnesium on the survival of bacteria in aqueous suspension. In Microbial Physiology and Continuous Culture, p. I02. London: H.M.S.O.

Strange, R. E., Dark, F. A. \& Ness, A. G. (196I). The survival of stationary phase Aerobacter aerogenes stored in aqueous suspension. J. gen. Microbiol. 25, 6I.

Thомаs, T. D. (1968). The metabolism of lactic acid bacteria. Ph.D. Thesis, Massey University, New Zealand.

Thomas, T. D. \& Batt, R. D. (1968). Survival of Streptococcus lactis in starvation conditions. J. gen. Microbiol. 50, 367.

Thomas, T. D. \& BatT, R. D. (1969a). A new method for the assay of glycolytic activity with special reference to micro-organisms. Analyt. Biochem. 28, 477.

Thomas, T. D. \& BatT, R. D. (1969b). Degradation of cell constituents by starved Streptococcus lactis in relation to survival. J. gen. Microbiol. 58, 347.

Thomas, T. D. \& BATT, R. D. (1969c). Synthesis of protein and ribonucleic acid by starved Streptococcus lactis in relation to survival. J. gen. Microbiol. 58, 363 .

Thomas, T. D., Lyttleton, P., Williamson, K. I. \& BatT, R. D. (I969d). Changes in permeability and ultrastructure of starved Streptococcus lactis in relation to survival. J. gen. Microbiol. 58, 38I.

WALKER, D. J. \& FORREST, W. W. (1964). Anaerobic endogenous metabolism in Streptococcus faecalis. J. Bact. 87, 250.

ZeVEnhUIZEN, L. P. T. M. (1966) Formation and function of the glycogen-like polysaccharide of Arthrobacter. Antonie van Leeuwenhoek 32, 356. 